\title{
Tiga Dekade Perkembangan Integrated Marketing Communications (IMC): Sebuah Literatur Review
}

\author{
Helpris Estaswara \\ Fakultas Ilmu Komunikasi, Universitas Pancasila \\ J1. Srengseng Sawah, Jagakarsa, Jakarta Selatan 12640.Telp: 081310488088, \\ E-mail: the.estaswara@yahoo.com
}

\begin{abstract}
Abstrak
Sejak kelahirannya, tiga dekade yang lalu hingga hari ini, IMC (Integrated Marketing Communications) telah menjadi perhatian para akademisi dan praktisi di seluruh dunia. Sebagai kajian yang relatif baru, penting untuk meninjau perkembangan IMC yang ditelusuri dari berbagai tulisan yang diterbitkan di jurnal-jurnal internasional terindeks sebagai bentuk manifestasi perkembangannya. Guna melihat perkembangan IMC selama tiga dekade ini dapat didasarkan pada tiga aspek, yaitu theoretical building, topik penelitian dan pengimplementasian IMC. Tujuannya untuk: (1) Melihat sejauhmana perkembangan IMC jika dilihat dari ketiga aspek tersebut dengan membandingkan deskripsi perkembangan sebelum tahun 2005? (2) Aspek apa yang berkembang paling signifikan sehingga beda dengan gambaran perkembangan IMC sebelum tahun 2008? Tahun 2005 dan 2008 dijadikan patokan karena pada saat itu riset perkembangan IMC secara teoretis (2005) dan topik-topik penelitian serta implementasinya (2008) telah dipublikasikan. Dengan menggunakan kajian literatur, penelitian ini menyimpulkan bahwa IMC terus berkembang secara teoretis, namun demikian tidak meninggalkan gagasan dasar yang telah dibangun pada tahun 2005. Hingga kini, teorisasi IMC semakin memertajam bangunan kontruksnya dan lebih bersifat multi-disipliner.
\end{abstract}

Kata Kunci: Perkembangan IMC, Teorisasi IMC, Topik penelitian, Implementasi IMC

\begin{abstract}
Since its inception, three decades ago until today, IMC (Integrated Marketing Communications) has become attention of academics and practitioners around the world. As a relatively new concept, it is important to review the development of IMC which is traced from various papers published in international journals indexed as a manifestation of its development. To identify the development of IMC over the past three decades, it can be based on three aspects, namely theoretical building, research topics, and IMC implementation. Aim of this article is to: (1) Describe IMC development that is viewed from three aspects by comparing before 2005? (2) What aspect is developed most significantly so that it is different from the description of IMC development before 2008? Year 2005 and 2008 were used as benchmarks because at that time research on development of IMC theoretical (2005), research topics, and its implementation (2008) had been published. Using literature review, this research concludes that the IMC continues to develop theoretically, but did not abandon the basic ideas that had been built in 2005 . Hitherto, theorization of IMC has sharpened in its construct and become more multi-disciplinary in nature.
\end{abstract}

Keywords: IMC development, IMC theorization, research topics, IMC implementation, 


\section{PENDAHULUAN}

Sejak kelahirannya, tiga dekade dan praktisi di seluruh dunia (Schultz, Kim \& Kang 2014; Muñoz-Leiva, Porcu \& del Barrio-García 2015; Šerić 2016; Schultz, Chu \& Zhao 2016). IMC yang pada awalnya digagas oleh para praktisi dari agensi periklanan (Schultz \& Schultz 2004; Estaswara 2008a; Estaswara 2011), dalam perkembangannya kemudian, para praktisi dan akademisi dari disiplin komunikasi dan pemasaran terlibat aktif dalam upaya pengembangannya, bahkan kajian IMC dianggap banyak berpengaruh dalam bidang pemasaran dan bisnis serta menjadi topik yang sering dibicarakan oleh para akademisi dan praktisinya (Schultz, Kim \& Kang 2014; Kliatchko 2008; Kitchen \& Schultz 2009; Luck \& Moffatt 2009; Johansen \&Andersen 2012)_alih-alih para pemikir dan pekerja komunikasi.

Faktanya, sejak dikenalkan secara akademis pada tahun 1989 sampai saat ini, puluhan artikel ilmiah tentang IMC, baik yang membicarakan seputar bangunan teori (theoretical-building) atau pengimplementasiannya, telah diterbitkan di berbagai jurnal internasional terideks, seperti Journal of Marketing Communications, Journal of Advertising, Journal of Advertising Research, International Journal of Advertising, Journal of Current Issues and Research in Advertising, European Journal of Marketing, dan Journal of Promotion Management (Schultz, Kim \& Kang 2014; Muñoz-Leiva, Porcu \& del Barrio-García 2015). Tulisan-tulisan yang telah diterbitkan di jurnal ilmiah tersebut, bukanlah sekedar laporan hasil penelitian yang terpisah antara satu dengan yang lainnya. Publikasi ilmiah dalam satu bidang kajian tertentu, dalam konteks tulisan ini adalah IMC, dapat yang lalu hingga hari ini, IMC (Integrated Marketing Communications) telah menjadi perhatian para akademisi dikatakan juga sebagai bentuk manifestasi atas perkembangan gagasan, pemikiran, konsep dan juga pengimplementasinya di lapangan (perusahaan). Sehingga, dengan melakukan literature review atas berbagai tulisan di jurnal-jurnal tersebut, bisa digunakan untuk memetakan sejauhmana perkembangan IMC sampai hari ini.

Untuk mengidentifikasi perkembangan IMC, dapat dilihat dari bangunan konseptualnya dan sejauhmana konseptualisasinya tersebut bisa diimplementasikan di berbagai perusahaan di seluruh dunia. Berdasarkan logika di atas, maka perkembangan IMC dapat dilihat dari tiga aspek, yaitu: (1) Gagasan (konsepsi) tentang IMC atau sejauhmana theoretical building yang telah ditulis; (2) Topik-topik penelitian IMC yang banyak ditulis dan diterbitkan; dan (3) Sejauhmana laporan atas pengimplentasian IMC yang telah dipublikasikan.

Berdasarkan pemikiran di atas, maka pertanyaan dalam penelitian ini adalah:

1. Sejauhmana perkembangan IMC jika dilihat dari ketiga aspek tersebut dengan membandingkan deskripsi perkembangan sebelum tahun 2005?

2. Aspek apa yang berkembang paling signifikan sehingga berbeda dengan gambaran perkembangan IMC sebelum tahun 2008?

Pemilihan batasan tahun 2005 dikarenakan pada tahun itu, dipublikasikannya untuk pertama kali sebuah literature review yang ditulis oleh Kliatchko terkait dengan 
perkembangan

(konseptualisasi)

pemikiran

komprehensif. Sedang pilihan tahun menyeluruh. Keduanya merupakan publikasi yang penting untuk menganalisis perkembangan IMC sampai saat ini (Schultz, Kim \& Kang 2014). Kedua tulisannya itu diterbitkan di International Journal of Advertising dengan judul "Towards a new definition of Integrated Marketing Communications (IMC)" (Vol 24, Issue 1, 2005, 7-24) dan "Revisiting the IMC construct: A revised definition and four pillars" (Vol 27, Issue 1, 2008, 133-160).

\section{KAJIAN LITERATUR \\ 1. Gagasan Tentang IMC (Theoretical Building)}

Kajian-kajian tentang IMC di jurnal-jurnal ilmiah terindeks penting untuk ditinjau guna melihat perkembangan teorisasinya, mengingat bahwa sebagai sebuah konsep atau teori yang relatif baru (tiga dekade), sejak awal kelahirannya IMC penuh dengan perdebatan (Eagle, Kitchen \& Bulmer 2007; Swain 2004; Tafesse \& Kitchen 2016). Perdebatan dan perbedaan konseptual, pada faktanya hanya akan memerlambat perkembangan IMC itu sendiri. Dengan demikian penting untuk mengidentifikasi sejauhmana perdebatan dan perbedaan secara konseptual dalam rangka theoretical building sampai hari ini, dan kontribusinya bagi perkembangan IMC.

Perkembangan gagasan tentang IMC (theoretical building), jika dirunut dari definisi pertama yang dipublikasikan pada tahun 1989, dapat dikelompokkan menjadi dua generasi pemikiran (Estaswara 2015, 2016). Generasi pertama, IMC merupakan integrasi berbagai elemen dalam promotional mix dengan pesan yang konsisten (one-voice). Ini merupakan
2008, karena pada tahun itu Kliatchko kembali memublikasikan tulisan tentang perkembangan penelitian IMC secara ide awal yang tertuang di dalam definisi IMC dari 4As (1989). Pasca definisi tersebut, pemikir-pemikir lain berusaha untuk menambah, memperkuat, mengembangkan dan juga mengoreksi gagasan tentang IMC (Kitchen \& Schultz 2009; Kliatchko 2005, 2008; Holm 2006; Burnet \& Moriarty 1998; Duncan \& Caywood 1996; Duncan \& Everett 1993; Nowak \& Phelps 1994; Kitchen et al 2004; Swain 2004; Fill 2002; Estaswara 2008a, 2008b, 2010). Upaya ini telah melahirkan beragam definisi dan konseptualisasi atas IMC, seperti Schultz et al (1993), Duncan (1993, 1996), Nowak \& Phelps (1994), dan Shimp (2003).

Pemikiran IMC generasi kedua lebih maju lagi, dengan melibatkan integrasi di semua departemen dalam perusahaan (Estaswara 2015, 2016). Gagasan IMC ini sudah diperluas dalam konteks organisasi/perusahaan (internal and external comunication), merek, stakeholder dan customer relationship dengan dukungan database yang berbasis teknologi komunikasi dan informasi. Para pemikir utama IMC generasi kedua adalah Schultz dan Schultz (2004), Kliatchko (2005, 2008) serta Duncan (2002).

\section{Topik-Topik Penelitian Seputar IMC}

Jika perdebatan atau perbedaan konseptualisasi IMC masih mengemuka, logikanya akan diturunkan menjadi topik-topik penelitian yang harus dilakukan. Di mana, hasilnya akan digunakan untuk mendukung atau bahkan memerkuat konseptualisasinya atas IMC. Sebagai contoh, perdebatan tentang definisi IMC pada awal-awal kelahirannya sebagai sebuah konsep, 
yang kemudian membuat para pemikir IMC melakukan survei terkait dengan definisi IMC kepada para praktisi dan \& Kitchen 1997; Kitchen \& Schultz 1999; Kim, Han, \& Schultz 2004; Kitchen et al 2004; Swain, 2004; Kitchen \& Li 2005; Estaswara, 2008b). Namun, jika tidak ada lagi perbedaan konsepsipara pemikirnya memiliki pemahaman yang relatif sama atas konseptualisasi IMC - maka topik-topik penelitiannya pada umumnya diturunkan dari aspekaspek dalam konsepsi IMC yang perlu dikaji dan dianalisis secara lebih mendalam (Kliatchko 2008; Estaswara 2008a; Kitchen \& Schultz, 2009).

Kembali menengok ke belakang, topik-topik penelitian IMC di masamasa awal pembangunan konsepsinya banyak mengangkat masalah definisi, persepsi, dan berbagai tantangan dalam pengimplentasian IMC (Kliatchko 2008; Estaswara 2008a). Sifatnya masih normatif, yaitu berangkat dari konseptualisasi IMC, lalu teorisasi itu dipaksakan untuk bisa diimplementasikan di perusahaan. Hasilnya, muncullah berbagai tantangan konseptual yang kemudian melahirkan banyak penelitian eksplorasi tentang siapa yang seharusnya memimpin pengimplementasian IMC, pengukuran efektivitas program IMC (outcome), hubungan clent dan agency, sampai keterlibatan top management (Estaswara 2008a, 2011a, 2011b; Kliatchko 2008, Kitchen \& Schultz 2009). Ini merupakan topik-topik penelitian yang mewarnai artikel di jurnal-jurnal internasional terindeks sampai tahun 2008.

\section{Pengimplentasian IMC}

Berdasarkan isu-isu seputar konseptualisasai IMC dan topik-topik penelitian yang telah dipublikasikan, barulah bisa diidentifikasi sejauhmana pengimplementasian IMC di perusahaan hasilnya dipublikasikan di jurnal-jurnal tersebut beserta analisis teoretisnya untuk menjelaskan apa itu IMC (Schultz dan seberapa besar gap antara praktik dan teori yang terjadi hingga hari ini. Kembali ke masa lalu, pengimplementasian IMC yang dilaporkan dalam jurnal-jurnal internasional terindeks sebelum tahun 2008 pada umumnya bersifat inside-out (belum berfokus pada konsumen), fokusnya hanya pada pesan, dan mengintegrasikan berbagai elemen promotional mix - walaupun beberapa penelitian diantaranya sudah memberi perhatian terhadap kebutuhan pelanggan (Kliatchko 2008).

Di sisi lain, model konseptual yang paling banyak digunakan sebagai basis mengidentifikasi dan menganalisis pengimplementasian IMC pada saat itu adalah "Four Evolutionary Stage of $I M C$ " yang dibangun oleh Schultz dan Schultz pada tahun 1998 (Schultz \& Schultz 2004; Estaswara 2008a; Kliatchko 2008).

\section{METODODOLOGI}

Guna menjawab kedua pertanyaan tersebut dapat dilakukan melalui literature review dari jurnaljurnal atau publikasi internasional yang telah disebutkan di atas. Metode ini merupakan metode yang banyak digunakan para pemikir dalam meneliti perkembangan IMC (Kliatchko 2008; Kitchen \& Schultz, 2009; Schultz, Kim \& Kang 2014; Muñoz-Leiva, Porcu \& del Barrio-García 2015) Di antara banyaknya publikasi ilmiah, teridentifikasi ada empat artikel yang relevan memberi gambaran perkembangan IMC sampai saat ini dan bisa digunakan sebagai basis analisis perkembangan. Pertama, hasil penelitian yang dilakukan Schultz, Kim dan Kang 
yang berjudul "Integrated Marketing Communication Research Its Limited Past and Huge Potential" yang Muñoz-Leiva, Porcu dan Barrio-García yang diterbitkan di International Journal of Advertising dengan judul "Discovering prominent themes in integrated marketing communication research from 1991 to 2012: a co-word analytic approach" (2015, 678-701). Ketiga, artikel berjudul "Content analysis of the empirical research on IMC from 2000 to 2015" yang ditulis Šerić di Journal of Marketing Communications (2016, 1-39). Ketiganya menggunakan metode kuantitatif dengan mengadopsi teknik analisis isi. Jurnal-jurnal ini dapat digunakan sebagai dasar dalam mengidentifikasi topik-topik penelitian dan pengimplementasian IMC.

Keempat, tulisan Tafesse dan Kitchen yang berjudul "IMC - an integrative review" yang diterbitkan di International Journal of Advertising (2016, 1-17). Berbeda dengan tiga artikel sebelumnya, tulisan ini menggunakan literatur review yang bersifat kualitatif. Dalam studi ini, artikel yang ditulis oleh Tafesse dan Kitchen digunakan untuk mengidentifikasi perkembangan konsep IMC sampai hari ini.

Keempat artikel tersebut merupakan literatur ilmiah utama yang tentunya masih dibutuhkan dukungan artikel-artikel lain yang relevan, khususnya artikel-artikel yang dipublikasikan oleh para pemikir utama IMC (di jurnal-jurnal internasional terindeks)_yang sejak awal konsep IMC dikenalkan, secara konsisten terus memberikan kontribusi pemikirannya, seperti Don Schultz (Nortwestern University), Philip J. Kitchen (ESC Rennes School of Business), Stephen J. Gould (The City University of New York), Jerry Kliatchko (University of diterbitkan dalam book chapter di The Handbook of International Advertising Research (2014, 457-483). Kedua,

Asia and the Pacific), dan Gayle Kerr (Queensland University of Technology).

Dengan demikian, dalam studi ini, literature review didefinisikan sebagai proses yang secara berurutan dan berulang-ulang dalam melakukan tinjauan literatur atas publikasi-publikasi ilmiah yang relevan dan dapat dipertanggungjawabkan - mulai dari mengumpulkan, mengetahui, memahami, mengaplikasikan, menganalisis, mensintesis dan mengevaluasi berbagai literatur tersebut. Hasil dari proses literature review harus mampu menunjukkan kontribusi baru bagi keseluruhan pengetahuan tentang IMC. Body of knowledge yang dibangun dengan metode literature review ini mengacu pada pengetahuan yang didukung berbagai penelitian lain secara kumulatif yang diperoleh melalui "building on each other's [research] results" (Levy \& Ellis, 2006, 182).

Gambar 1.

Proses Literature Review dalam studi (Sumber:Diadopsi dari Levy \& Ellis (2006:182)

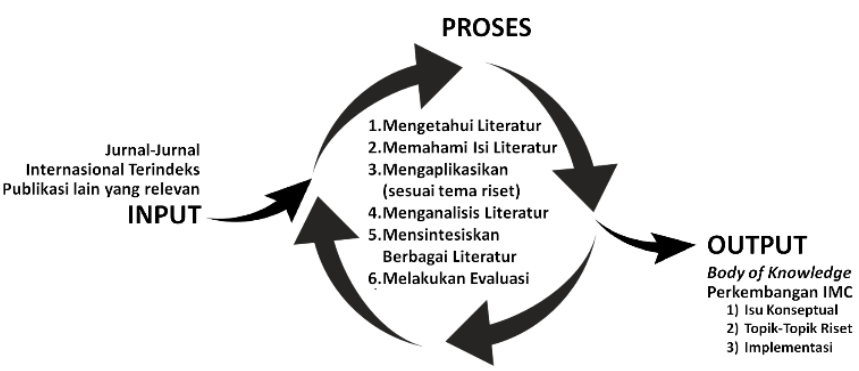

\section{HASIL DAN PEMBAHASAN}

\section{Perkembangan Gagasan Tentang IMC}

Artikel yang ditulis oleh Tafesse dan Kitchen dengan judul "IMC - an integrative review" (2016, 1-17) dapat digunakan sebagai starting point untuk membahas perkembangan gagasan IMC (conceptual isues) dalam rangka 
theoretical building. Mereka telah melakukan tinjauan mendalam terhadap tiga konseptualisasi IMC yang lagi theoretical disegreement dari para pemikir IMC dengan cara menyintesiskan ketiga gagasan IMC tersebut. Sebenarnya, kecenderungan ada kesamaan pandangan antar pemikir IMC sudah teridentifikasi sejak 2005 (Kliatchko 2005; Estaswara 2008a) dan juga dukungan dari semua pemikir, termasuk para praktisi, terhadap IMC (Kitchen \& Schultz 2009), meski menggunakan terminologi/nama yang berbeda-beda, selain IMC, seperti "integrated thinking", "integrated planning", "integrated marketing", "360", "full service" atau hanya satu kata saja,"integration" (Kliatchko \& Schultz 2014, 380). Variasi penyebutan IMC dengan terminologi lain ini, juga teridentifikasi pada tahun 2005, dengan jumlah yang lebih banyak dan lebih bervariasi (Kliatchko 2005).

Dari ketiga konseptualisasi tersebut, Tafesse dan Kitchen (2016) melakukan analisis berdasarkan delapan poin untuk mencari kesamaan pemikiran, yaitu IMC outcome, integration scope, audience scope, relational episode, massage source, media channels, integration modes, organisational support process, dan feedback (Tafesse \& Kitchen 2016, 3). Jika dirangkum, delapan aspek tersebut dapat dilihat pada tabel di bawah ini: 
Tiga Dekade Perkembangan Integrated Marketing Communications (IMC): Sebuah Literatur Review

Tabel 1: Gambaran Elaborasi Konsepsi IMC (Diolah dari Tafesse dan Kitchen 2016, 3)

\begin{tabular}{|c|c|c|}
\hline NO & ASPEK ANALISIS & ELABORASI TIGA TEORISASI IMC \\
\hline 1 & IMC outcome & $\begin{array}{l}\text { Tiga kelompok outcome, yaitu: (1) Tactical } \\
\text { (consumer response: image, cognitive, afective dan } \\
\text { behavioral); (2) Intermediate (information, } \\
\text { knowledge dan satisfaction dari customer); (3) } \\
\text { Strategic (brand equity, brand value, market share, } \\
\text { dan profitability). }\end{array}$ \\
\hline 2 & Integration scope & $\begin{array}{l}\text { Campaign level dan organisation level di mana } \\
\text { integrasinya bisa bersifat taktis, fungsional atau } \\
\text { strategis. }\end{array}$ \\
\hline 3 & Audience scope & $\begin{array}{l}\text { Consumer/customer dan stakeholder lainnya. } \\
\text { Konsumen atau pelanggan fokus pada upaya } \\
\text { pemasaran, sedangkan stakeholder fokus pada } \\
\text { pembangunan dukungan yang positif dari pihak- } \\
\text { pihak lain yang signifikan bagi perusahaan. }\end{array}$ \\
\hline 4 & Relational episode & $\begin{array}{l}\text { Short-term (transactional) dan ongoing } \\
\text { (relational). Transactional fokus pada terciptanya } \\
\text { pembelian (hard-selling), sedang relational fokus } \\
\text { pada loyalitas (soft-selling). }\end{array}$ \\
\hline
\end{tabular}




\begin{tabular}{|c|c|c|}
\hline NO & ASPEK ANALISIS & ELABORASI TIGA TEORISASI IMC \\
\hline 5 & Massage source & $\begin{array}{l}\text { Fokus pada brand (merek) dan customized sesuai } \\
\text { dengan target audience-nya. Ada tiga sumber yang } \\
\text { bisa digunakan dalam pembangunan pesan IMC, } \\
\text { yaitu: (1) Bersumber dari marketing (product } \\
\text { design, customer service dan distribution points); } \\
\text { (2) Bersumber dari organisasi (business practices, } \\
\text { corporate culture, dan corporate philosophies); (3) } \\
\text { Bersumber dari komunikasi (advertising, public } \\
\text { relations, dan sales promotions). }\end{array}$ \\
\hline 6 & Media channels & $\begin{array}{l}\text { Prinsip media channels dalam IMC adalah } \\
\text { optimalisasi, baik media reach atau kemampuan } \\
\text { interaksinya. Media reach umumnya digunakan } \\
\text { untuk media tradisional (termasuk juga all customer } \\
\text { touch points), sedangkan interaksi untuk media } \\
\text { online. }\end{array}$ \\
\hline 7 & Integration modes & $\begin{array}{l}\text { Merupakan eksekusi dari strategi yang berupa } \\
\text { kegiatan komunikasi. Prinsipnya adalah effective } \\
\text { communication dengan memerhatikan: (1) } \\
\text { Communication consistency (berbasis merek dan } \\
\text { media/alat secara kontekstual); (2) Communication } \\
\text { customization (keselarasan pesan, media dan } \\
\text { audience); (3) Communication interactivity } \\
\text { (meaning co-creation melalui share meaning dalam } \\
\text { komunikasi dua arah). }\end{array}$ \\
\hline 8 & Organisational support process & $\begin{array}{l}\text { Dukungan organisasi yang diperlukan untuk } \\
\text { implementasi IMC sangat bervariasi, dari customer } \\
\text { database, information technology, cross-funtional } \\
\text { coordination and planning, outside-in planning, } \\
\text { sampai dukungan top management (corporate } \\
\text { focus). }\end{array}$ \\
\hline 9 & Feedback & $\begin{array}{l}\text { Merupakan bagian dari evaluasi internal terkait } \\
\text { dengan customer response yang dapat digunakan } \\
\text { sebagai dasar pengambilan keputusan manajemen. }\end{array}$ \\
\hline
\end{tabular}


Tiga Dekade Perkembangan Integrated Marketing Communications (IMC): Sebuah Literatur Review

Berdasarkan tabel di atas, dapat dikatakan bahwa gagasan-gagasan dasar IMC di atas sebenarnya telah dirumuskan sejak kajian ini dikenalkan sampai 2005, atau selaras dengan konsep-konsep yang dibangun dalam first generation of IMC yang bersifat tactical, dan konseptualisasi IMC dalam second generation yang bersifat strategis. Setelah itu, berbagai perubahan yang terjadi dilakukan dengan mensintesiskan berbagai konsep atau gagasan yang ada, seperti yang dilakukan oleh Tafesse dan Kitchen (2016) di atas. Walaupun menghasilkan kontribusi baru, tapi sebenarnya tidak mengubah pondasi konseptualnya secara mendasar.

Demikian juga kontribusi dari Kerr dan Patti (2015) terkait konseptualisasinya tentang strategic integration yang merupakan konsep penting dalam IMC dan yang membedakannya dengan marketing communication. Padahal, strategic integration sendiri merupakan konsep yang telah diungkapkan pada awal pembangunan IMC (konsepsi dalam second generation) yang terus diperbarui dan dipertajam melalui pengoperasionalisasian konstruk (Kerr \& Patti 2015), maupun mengelaborasikan secara konseptual dengan disiplin-disiplin lain, seperti corporate marketing dan corporate communication (Johansen \& Andersen 2012).

Dengan demikian, bisa dikatakan bahwa konseptualisasi tentang IMC semakin berkembang. Bangunan teorinya menjadi lebih kompleks dengan fokus yang lebih luas, yang dilakukan dengan memertajam konsep atau melakukan operasionalisasi konstruk, mengelaborasikan dengan konsep atau disiplin ilmu lain, namun konsep dasarnya tidak berubah dari masa-masa awal pembangunan IMC sebagai disiplin baru (sebelum 2005).

\section{Perkembangan Topik-Topik Penelitian IMC}

Menganalisis persoalan ini dapat diawali dengan meninjau tulisan Schultz, Kim dan Kang (2014), Muñoz-Leiva, Porcu dan del Barrio-García (2015) dan Šerić (2016). Ketiga artikel ilmiah tersebut memberi gambaran tentang topik-topik penelitian IMC yang telah dipublikasikan selama ini di jurnaljurnal internasional terindeks.

Pertama, Schultz, Kim dan Kang (2014) yang menganalisis 65 artikel dari tahun 1993 sampai 2009 (17 tahun) di tujuh jurnal internasional, mengemukakan bahwa topik-topik yang banyak diteliti adalah persepsi (20 artikel), definisi (18 artikel), brand (8 artikel), dan pengukuran (6 artikel), sisanya bervariasi seputar media, interaktivitas dan organisasi.

Kedua, Muñoz-Leiva, Porcu dan del Barrio-García (2015) telah menganalisis 139 publikasi yang diterbitkan dari tahun 1991 sampai 2012 (selama 21 tahun) di 11 jurnal internasional, menemukan ada empat kelompok topik yang banyak diteliti, yaitu: (1) Penelitian tentang IMC dan berbagai isu penting yang terkait (seperti promotional mix, communication strategy, branding, stakeholder, dan teknologi informasi) (60 artikel); (2) Studi-studi awal tentang persepsi dan paradigma terkait IMC (36 artikel); (3) Kaitan IMC dengan disiplin ilmu lain (Public Relations dan Marketing) (39 artikel); (4) Kajian tentang aspek teoritis 
IMC (22 artikel). Sebagai catatan, satu artikel bisa mengangkat lebih dari satu topik penelitian.

$$
\text { Ketiga, Šerić }
$$

menganalisis 80 artikel dengan menggunakan mixed method yang diterbitkan dari tahun 2000-2015 (16 tahun), menyimpulkan bahwa topiktopik yang banyak diteliti adalah: (1) IMC Implementation (46,25\%)—yang umumnya terkait dengan tingkat implementasi IMC dan hambatannya; (2) IMC Impact (40\%) - umumnya terkait dengan brand, customer dan business performance; IMC Perception (36,25\%); (4) IMC Measurement (18,75\%); (5) IMC-Technology Relationship (15\%).

Berdasarkan hasil ketiga penelitian di atas, secara umum dapat dikatakan bahwa topik penelitian yang banyak diteliti dan dipublikasikan di jurnal-jurnal internasional terindeks adalah persepsi. Topik ini umumnya mengeksplorasi tentang apa itu IMC dan bagaimana perkembangannya sebagaisebuah konsep dengan cara melakukan survei kepada akademisi dan praktisi dari berbagai profesi (ads agency, public relations officer, marketing dan top management). Topik ini banyak diteliti oleh para pemikir utama antara 1998 sampai 2009 (Schultz, Kim \& Kang 2014; Muñoz-Leiva, Porcu \& del Barrio-García 2015), dan diteliti oleh para pemikir lain (selain peneliti utama) dengan melakukan survei lokal (di negara masing-masing) sejak 2010 sampai 2016 (Šerić 2016).

Meskipun hasil studi yang dilakukan Šerić (2016) mengungkapkan bahwa IMC Implementation dan IMC Impact merupakan topik-topik yang paling banyak diteliti, namun topik-topik ini umumnya masuk dalam bagian studi- studi persepsi tentang IMC (Eagle \& Kitchen 2000; Kim, Han, \& Schultz 2004; Swain 2004; Kitchen, et al. 2004; Kitchen \& Li 2005; Estaswara 2008a; Kelly, Kerr \& Drennan 2010; Laurie \& Mortimer 2011; Kliatchko \& Schultz 2014). Hasil ini menunjukkan bahwa konsepsi tentang IMC terus dieksplorasi secara empiris, melalui survei atau FGD (Focus Group Discussdion) terhadap aktor-aktor yang terkait pengimplementasian IMC di perusahaan. Penelitian-penelitian seperti ini umumnya bertujuan untuk menggambarkan pemahaman tentang IMC, sehingga tidak jauh relevansinya dengan topik-topik yang mengangkat definisi atau aspek-aspek teoretisasi IMC (Schultz, Kim \& Kang 2014; Muñoz-Leiva, Porcu \& del BarrioGarcía 2015).

Penelitian seperti ini memiliki pola penyebaran yang sama dengan topik persepsi tentang IMC. Pada awal IMC dikenalkan, topik-topik tentang analisis dan pembangunan definisi sudah banyak dilakukan (tahun 1998 sampai 2009) (Kliatchko 2008), yang terus berkembang dengan memertajam aspekaspek teoretis dalam IMC dengan melakukan operasionalisasi konstruk (Kerr \& Patti 2015) — mengurai aspekaspeknya secara lebih mendalam, atau mengolaborasikannya dengan disiplin lain (Johansen \& Andersen 2012).

Terakhir, penelitian tentang implementasi IMC dan hambatannya menjadi topik yang banyak diteliti (Šerić 2016) sejak tahun 1993 (Kliatchko 2008) sampai 2015 (Šerić 2016). Jumlah ini belum termasuk artikel-artikel publikasi lain yang semakin banyak jumlahnya dan tersebar di seluruh dunia. Studi atas implementasi IMC pada umumnya mengeksplorasi tentang degree of 
implementation yang didasarkan four-stage model of IMC implementation yang dibangun oleh Schultz dan Schultz (1998). Kliatchko (2008) menambahkan empat pilar pada model tersebut. Akhirnya, Dahl, Eagle, dan Low (2015) merumuskan satu tahap lagi, menjadi five-stage model of IMC implementation (2015, 236) bagi kajian IMC di bidang social marketing.

\section{Perkembangan Implementasi IMC}

Seperti yang telah diungkapkan di muka, konsep IMC berkembang semakin luas dan kompleks dengan mengolaborasi berbagai disiplin ilmu yang relevan. Perkembangan teorisasi IMC seperti ini membuat gap yang semakin jauh antara konsep dengan praktik (implementasi). Hal ini membuat IMC menjadi sulit dipahami dan dipraktekkan (Luck \& Moffatt 2009). Mengutip Šerić (2016), IMC Implementation $(46,25 \%)$ merupakan topik yang paling banyak ditelititerkait tingkat implementasi dan hambatannya-namun dalam implementasinya, umumnya didasarkan pada four-stage model of IMCimplementation yang dibangun oleh Schultz dan Schuiltz di tahun 1998. Temuan ini semakin menunjukkan bahwa perkembangan konsep IMC tidak diikuti atau untuk sulit di mplementasikan di perusahaanperusahaan.

Hasil studi Šerić (2016) menunjukkan bahwa implementasi IMC masih pada tahap kedua dari four-stage model of IMC implementation, yaitu mengimplementasikan IMC dengan memerhatikan needs and wants konsumen (consumer-based), merancang pesan komunikasi dengan ide-ide yang sudah ada. Mengingat juga, tiga pemikiran IMC prinsip one-voice atau kesamaan pesan; dan menggunakan media komunikasi (offline dan online) yang tepat, serta diaplikasikan berdasar prinsip integrasi (Schultz \& Schultz 1998). Tak hanya itu, beberapa artikel, implementasi IMC sudah memanfaatkan teknologi informasi guna membangun database konsumen. Secara umum, sifatnya masih pada tataran moderat, namun sudah strategis, meski hanya tataran pesan dan media (Šerić 2016). Hal ini mengingat bahwa implementasi IMC menghadapi banyak hambatan secara internal, termasuk tidak adanya dukungan dari manajemen puncak (top management), koordinasi antar bagian dan perencanaan yang bersifat cross-fuctional yang sulit dilakukan (Schultz, Kim \& Kang 2014; Johansen \& Andersen 2012; Kerr \& Patti 2015).

\section{Perkembangan IMC}

Apakah IMC benar-benar berkembang? Pertanyaan ini merupakan pertanyaan utama yang harus dijawab dalam tulisan ini. IMC sebagai sebuah konsep terus berkembang sejak 2008. Berbagai literatur menunjukkan tidak ada lagi perdebatan konseptual yang signifikan. Gagasan tentang IMC dari para pemikir utamanya relatif memiliki kesamaan dalam semua ide dasar. Pengembangan konseptualnya mengarah pada pendalaman ide-ide dasar dengan mengolaborasikan disiplin ilmu lain, seperti pemasaran, manajemen strategis, teknologi informasi, keuangan, komunikasi organisasi, brand management, public relations, dan stakeholder relations.

Berbicara kajian Tafesse dan Kitchen (2016) terkait dengan delapan aspek konseptualisasi IMC, pada dasarnya hanya memertajam konsep atau yang dielaborasikan dalam tulisan tersebut merupakan gagasan yang telah 
diterbitkan sebelum tahun 2000. Kajian ini, secara prinsip juga memiliki relevansi dengan gagasan Kliatchko tentang four pillars of IMC yang diterbitkan pada tahun 2008, yaitu stakeholder (multi-audience), content (brand and incentives), channel (online and offline media), dan results (customer based/ROCI) dalam konteks business process (brand and corporate level) (Kliatchko 2008).

Walaupun Kliatchko (2008) hanya menjelaskan empat elemen IMC, sedangkan Tafesse dan Kitchen (2016) mengungkapkan delapan elemen, perbedaan yang mendasar dari keduanya hanyalah terletak pada persoalan konseptualisasi atas konstruk IMC atau pendalaman gagasan-gagasan utama yang sudah ada dengan mengeksplorasi konsep IMC secara lebih detail dan mendalam, serta mengolaborasikan dengan disiplin ilmu lain. Termasuk gagasan Kerr dan Patti (2015) tentang strategic integration dalam IMC yang memertajam konsep utama berbasis disiplin strategic management. Di luar itu, tidak ada sesuatu yang baru dari konseptualisasi IMC.

Lebih lanjut, terkait dengan perkembangan penelitian tentang IMC, topik-topik penelitian di berbagai jurnal internasional terindeks secara umum sudah tidak lagi fokus pada masalah konseptualisasi IMC, tapi sudah bergeser pada pengimplementasian IMC. Dengan cara mengeksplorasi pengimplementasian IMC, baik secara kualitatif maupun kuantitatif, hasilnya 2019).

(Vollero, Schultz \& Siano,

\section{Aspek yang Berkembang Paling}

IMC di perusahaan yang telah dipublikasikan di berbagai jurnal internasional terindeks, aspek konseptual merupakan aspek yang digunakan untuk memertajam konseptualisasi IMC dan bagaimana mengimplementasikannya. Topik penelitian yang mengangkat persepsi dari aktor-aktor yang terlibat dalam pengimplementasian IMC (seperti $A d s$ Agency, Public Relations Agency atau Officers sampai Marketer dan Top Management), maupun penelitian atas definisi IMC sudah jarang diteliti. Ini merupakan topik-topik penelitian yang banyak dipublikasikan sebelum tahun 2008 (Kliatchko 2008; Estaswara 2008a; Schultz, Kim \& Kang 2014; MuñozLeiva, Porcu \& del Barrio-García 2015; Šerić 2016).

Terakhir, masalah implementasi IMC jika dibandingkan dengan konseptualisasi yang semakin kompleks, menyebabkan gap antara praktek dan teori menjadi semakin tinggi. Teorisasi IMC yang terus berkembang, meski tidak mengubah gagasan-gagasan dasar yang sudah disepakati oleh para pemikir utama dalam kajian ini, menyebabkan jurang perbedaan yang semakin tinggi antara konsep dengan pengimplementasiannya. Bahkan, IMC semakin susah untuk diimplementasikan di lapangan (Kliatchko \& Schultz 2014; Schultz, Chu \& Zhao 2016; Šerić 2016). Kembali meninjau gagasan dasar IMC sebelum tahun 2008, gap antara teori dan praktik sebenarnya sudah muncul (Kliatchko 2008; Estaswara 2008a), dan sekarang gap tersebut semakin jauh karena bangunan konseptual IMC yang semakin dalam dan multi-disipliner

\section{Signifikan}

Dari ketiga aspek yang diteliti, yaitu theoretical building IMC, topik penelitian IMC, dan pengimplentasian berkembang paling signifikan. Pembahasan dari berbagai tulisan, umumnya berujung pada kontribusi baru terhadap bangunan teorisasi IMC dan 
berbagai isu yang belum terselesaikan, khususnya isu integrasi, kepemimpinan dan pengukuran program IMC (Schultz, Chu \& Zhao 2016; Kerr \& Patti 2015; Tafesse \& Kitchen 2016).

\section{SIMPULAN REKOMENDASI}

Selama tiga dekade sejak kemunculannya di ruang akademis di tahun 1989, bagaimana pun juga, IMC terus berkembang sampai hari ini. Pembangunan teori IMC (theoretical building) masih banyak ditulis dan dipublikasikan, baik mengoperasionalkan konstruk IMC menjadi lebih applicable untuk dipraktekkan atau lebih mendalam dan meluas secara konseptual, serta mengolaborasikannya dengan disiplin ilmu lain yang akhirnya membangun IMC menjadi kajian yang multidisipliner.

Penelitian ini memberi gambaran tentang perkembangan IMC dan bangunan teoretisnya yang tidak bisa dilepaskan dari apa yang sudah dibangun sebelum tahun 2005. Memelajari IMC hari ini, harus dipahami terlebih dahulu konsep-konsep dasar yang telah disepakati oleh para pemikirnya pada masa-masa awal IMC muncul. Dengan demikian, dua generasi pemikiran IMC (first and second generation) seperti yang telah diungkapkan di bagian depan, masih relevan dikaji sebagai dasar untuk memahami arah perkembangan teorisasi IMC.

IMC yang pada awalnya communications and social marketing. Journal of SocialMarketing, Vol. meredefinisi disiplin advertising, marketing, marketing communication dan public relations, kini telah berkembang dengan membasiskan pondasi pemikirannya pada disiplin ilmu lain, khususnya bisnis dan pemasaran. Kajian IMC yang berbasis ilmu komunikasi semakin jarang ditemui (Holm 1996; Groom 2011; Johansen \& Andersen 2012; Porcu, del Barrio-García \& Kitchen 2012). Berangkat dari kenyataan itu, maka agenda penelitian ke depan terkait dengan disiplin komunikasi, alangkah baiknya untuk kembali membahas IMC dan berbagai persoalan teoretisnya dalam kerangka kajian ilmu komunikasi. Tidak hanya itu, juga perlu mengkaji brand communication dalam IMC (Estaswara 2012; Keller 2016), ataupun kajian tentang media IMC (Batra \& Keller 2016; Vollero, Schultz \& Siano, 2019).

\section{DAFTAR PUSTAKA}

Batra, R., \& Keller, K. L. (2016). Integrating Marketing Communications: New Findings, New Lessons, and New Ideas. Journal of Marketing, 80, 122145.

Burnett, J. J., \& Moriarty, S. (1998). Introduction to marketing communications. An integrated approach. New Jersey: PrenticeHall.

Dahl, S., Eagle, L., \& Low, D. (2015). Integrated marketing

5(3), 226-240.

Duncan, T., \& Everett, S. (1993). Client 
perceptions of integrated marketing communications. Journal of Advertising Research, 33 (3) 3039.

Duncan, T., \& Caywood, C. (1996). The concept, process and evolution of Integrated Marketing Communication. Dalam Thorson, E. \& Moore, J. (Eds). Integrated communication: A synergy of persuasive voices. New Jersey: Lawrence Erlbaum Associates.

Duncan, T. (2002). IMC: Using advertising and promotion to build brands. New York: McGraw-Hill.

Eagle, L., \& P. Kitchen. (2000). IMC, brand communications, corporate cultures. European Journal of Marketing, 34(5), 667-686.

Eagle, L., Kitchen, P. J., \& Bulmer, S. (2007). Insights into interpreting integrated marketing communications. European Journal of Marketing, 41(7/8), 956-970.

Estaswara, H. (2008a). Think IMC!: Efektivitas Komunikasi untuk Meningkatkan Loyalitas Merek dan Laba Perusahaan. Jakarta: Gramedia.

Estaswara, H. (2008b). The Implementation process of IMC (Integrated Marketing Communications) and its future prospect in business practice in Indonesia: An exploratory comparative study toward four profession groups. Indonesian Journal of Communication Studies, 1(1), 73-83.

Estaswara, H. (2010). Stakeholder relationships in Integrated

Marketing Communications (IMC): A theoretical perspective. Journal of Strategic Communication, 1(1), 61-75.

Estaswara, H. (2011a). Agensi vis-à-vis Client: Siapa yang Seharusnya Pegang Kendali atas Program Integrated Marketing Communications (IMC)? Prosiding Konferensi Nasional Komunikasi (KNK) UI, 585-598.

Estaswara, H. (2011b). Apakah IMC (Integrated Marketing Communications) Dibutuhkan di Indonesia? Prosiding Konferensi Nasional Komunikasi (KNK) UI, 305-319.

Estaswara, H. (2012), Brand management mapping: An integrated marketing communications (IMC) perspective. Dalam N. Sarasnatiti, F. Lengkong, \& M. Sintawati (Eds.), Enterpreneurship in Global Competition. Jakarta: Universitas Atmajaya Publication, 419-436.

Estaswara, H. (2015). Integrated Marketing Communications (IMC): Extended Version or New Idea? Journal of Global Academic Institute Education \& Social Sciences, 1(2), 123-139.

Estaswara, H. (2016). Integrated Marketing Communication (IMC) in Higher Education in Indonesia. Polish Journal of Management Studies, 14(1), 74-83.

Fill, C. (2002). Marketing communications-Contexts, strategies and applications. Prentice Hall: Harlow.

Groom, S. A. (2011). The Next Integration: IMC and the Field of 
Tiga Dekade Perkembangan Integrated Marketing Communications (IMC): Sebuah

Communication. The Review of Communication, 11(2), 145-160.

Holm, O. (2006). Integrated marketing communication: From tactic to strategy.

CorporateCommunications, 11(1), 23-43.

Johansen, T. S., \& Andersen, S. E. (2012). Co-creating ONE: rethinking integration within communication. Corporate Communications: $\quad A n$ International Journal, 17(3),272-288.

Keller, K. L. (2016). Unlocking the Power of Integrated Marketing Communications: How Integrated Is Your IMC Program? Journal of Advertising, 45(3), 286-301.

Kelly, L., Kerr, G., \& Drennan, J. (2010). Avoidance of Advertising in Social Networking Sites. Journal of Interactive Advertising, 10(2),

Perceptions of Integrated Marketing Communications: A Chinese ad and PR agency perspective. International Journal of Advertising, 24(1), 51-78.

Kitchen P. J., Brignell, J., Li, T., \& Jones, G. S. (2004). The emergence of IMC: A theoretical perspective. Journal of Advertising Research, 44(1), 1930.

Kliatchko, J. \& Schultz, D. E. (2014). Twenty years of IMC: A study of CEO and CMO perspectives in the Asia-Pacific region. International Journal of Advertising, 33(2), 373-390.

Kliatchko, J. (2005). Towards a new definition of Integrated Marketing Communications (IMC). International Journal of Advertising, 24(1), 7-34.

Kliatchko, J. (2008). Revisiting the IMC
16-27.

Kerr, G., \& Patti, P. (2015). Strategic IMC: From abstract concept to marketing management tool. Journal of Marketing Communications, 21(5), 317339.

Kim, I., Han, D., \& Schultz, D. E. (2004). Understanding the diffusion of integrated marketing communications. Journal of Advertising Research, 44(1), 3145.

Kitchen P. J., \& Schultz, D. E. (1999). A multi-country comparison of the drive for IMC. Journal of Advertising Research, 39(1), 2136.

Kitchen, P. J., \& Schultz, D. E. (2009). IMC: New horizon/false dawn for a market place in turmoil. Journal of Marketing Communication, 15(2), 197-204.

Kitchen P. J., \& Li, T. (2005). construct: A revised definition and four pillars. International Journal of Advertising, 27(1), 133-160.

Laurie, S., \& Mortimer, K. (2011). IMC is dead. Long live IMC': Academics' versus practitioners' views". Journal of Marketing Management, Vol. 27(13/14), 1464-1478.

Levy, Y., \& Ellis, T. J. (2006). A Systems Approach to Conduct an Effective Literature Review in Support of Information Systems Research. Informing Science Journal, 9, 181-212.

Luck, E., \& Moffatt, J. (2009). IMC: Has anything really changed? A new perspective on an old definition. Journal of Marketing Communications, 15(5), 311325.

Muñoz-Leiva, F., Porcu, L., \& del 
Barrio-García. (2015). Discovering prominent themes in integrated marketing communication research from 1991 to 2012: a coword analytic approach. International Journal of Advertising, 34(4), 678-701.

Nowak, G. J. \& Phelps, J. (1994). Conceptualizing the integrated marketing communications' phenomenon: An examination of its impact on advertising practices and its implications for advertising research. Journal of Current Issues and Research in Advertising, 16 (1), 49-66.

Porcu, L., del Barrio-Garcia, S., \&. Kitchen P. J. (2012). How Integrated Marketing Communications (IMC) works? A theoretical review and an analysis of its main drivers and effects. Comunicacion $Y$ Sociedad, XXV(1), 313-348.

Schultz, D. E., Tannenbaum, S. I., \& Lauterborn, R. F. (1993). Integrated Marketing Communications. Lincolnwood, IL: NTC Business Books.

Schultz, D. E., \& Kitchen, P. J. (1997). Integrated marketing communications in us advertising agencies: An exploratory study. Journal of Advertising Research, 37(5) 718.

Schultz, D. E., \& Schultz, H. F. (1998). Transitioning marketing communication into the twentyfirst century. Journal of Marketing Communications, 4(1), 9-26.

Schultz, D. E., \& Schultz, H. F. (2004). IMC: The Next Generation: Five Steps for Delivering Value and Measuring Returns Using Marketing Communication. US:
McGraw Hill.

Schultz, D. E., Kim, I., \& Kang, K. (2014). Integrated Marketing Communication Research Its Limited Past and Huge Potential. Dalam Cheng, H. (Eds.), The Handbook of International Advertising Research. India: John Wiley \& Sons, Ltd., 457483.

Schultz, D., Chu, G., \& Zhao, B. (2016). IMC in an emerging economy: the Chinese perspective. International Journal of Advertising, 35(2), 200-215.

Šrić, M. (2016). Content analysis of the empirical research on IMC from 2000 to 2015. Journal of Marketing Communications, http://dx.doi.org/10.1080/13527 266. 2016.1184708.

Swain, W.N. (2004). Perceptions of IMC after a decade of development: who's at the wheel, and how can we measure success? Journal of Advertising Research, 44(1), 4665.

Tafesse, W., \& Kitchen, P. J. (2016). IMC - an integrative review. International Journal of Advertising, http://dx.doi.org/10.1080/02650 487.2015.1114168.

Vollero, A., Schultz, D. E., \& Siano, A. (2019). IMC in digitallyempowering contexts: the emerging role of negotiated brands. International Journal of Advertising, DOI: 10.1080/02650487.2018.153522 1. 